\title{
First report on metagenomic analysis of gut microbiome in Island Flying Fox (Pteropus hypomelanus) revealing latitudinal correlation as opposed to host phylogeny in island populations of Malaysia
}

\author{
Nur Syafika Mohd-Yusof ${ }^{1}$, Muhammad Abu Bakar Abdul-Latiff², Abd Rahman \\ Mohd-Ridwan $^{1}$, Aqilah Sakinah Badrulisham ${ }^{1}$, Salmah Yaakop ${ }^{1}$, Shukor Md-Nor ${ }^{1}$, and \\ BADRUL MUNIR MD-ZAIN ${ }^{1}$ \\ ${ }^{1}$ Universiti Kebangsaan Malaysia \\ ${ }^{2}$ Universiti Tun Hussein Onn Malaysia
}

June 3, 2020

\begin{abstract}
Flying fox (Pteropus hypomelanus) belongs to the frugivorous bats, which play a crucial role in maintaining proper functioning of an ecosystem and conservation of environment. Bats are well known carriers of pathogenic viruses such as BatCov RaTG13 from the coronavirus family that share $90.55 \%$ with SARS-CoV-2, the pathogen causing recent global pandemic coronavirus disease 19 (COVID-19). However, bats' possible role as a carrier of pathogenic bacteria is less explored. Here, using metagenomic analysis through high-throughput sequencing, we explored the gut microbiome composition of different island populations on the east and west coasts of Peninsula Malaysia. The 16S rRNA gene in samples from Redang Island, Langkawi Island, Pangkor Island and Tinggi Island was amplified. Bacterial community composition and structure were analyzed with $\alpha$ and $\beta$ diversity metrics. In contrast to recent studies of host-microbe associations in other mammals, we found no correlation between host phylogeny and bacterial community dissimilarity across four island populations. Our analyses suggest that the significant linear relationship between Redang Island and Langkawi Island implies high bacteria diversity which supporting latitudinal correlation. We found geographic locality is a strong predictor of microbial community composition and observed a positive correlation between ecological features and bacterial richness.
\end{abstract}

\section{Introduction}

Bats are capable of flying high and covering long distance during seasonal migrations, and they have extraordinary adaptation, being able to inhabit a huge number of diverse ecological niches (Mühldorfer, 2013). These characteristics have led to increased global interest in bats as potential reservoir hosts and vectors of zoonotic pathogens (Kuzmin et al., 2011; Wang, Walker, \& Poon, 2011). Current global pandemic indicates that bats and pangolins are among wildlife associated with spread of human coronavirus that causes COVID19 (Cui, Li, \& Shi, 2019; Zhang, Wu, \& Zhang, 2020). In addition, frugivorous bats play a crucial role in dispersing seeding and maintaining forest tree diversity and regeneration (Muscarella \& Fleming, 2007). A recent study by Aziz et al., (2017a) reported that one of the most important crops in Southeast Asia, durian (Durio zibethinus), depends largely on island flying fox during pollination. By examining gut microbiome of flying fox, we aimed to shed light on their ability to carry out these ecosystem services as well as identifying potential threats caused by rapid and continuous habitat destruction.

Early microbiome studies on wildlife focused on primates which represent only $5 \%$ of the diversity of extant mammals (Wilson \& Reeder, 2005). The gut microbiome refers to the bacteria found in the intestinal tract. 
Studies on the human gut microbiome have found that the gut microbiome has larger influence on various aspects of host health than initially thought. Every individual has a unique gut microbiota profile that plays a role in host nutrient metabolism, immunity, and protection against pathogens. It acts as a barrier against harmful microbes by competing for nutrients and ecological binding sites (Buffie \& Pamer, 2013) and producing antimicrobial substances (Ubeda et al., 2013). Recent technological advances have led to an increasing number of gut microbiome studies. However, many studies in the field investigate the role of gut microbiome in human, domestic animals, or laboratory models. Therefore, information on microbiome functions in mammalians is limited to only a few taxa, leaving the broader patterns of microbiome function and evolution unexplored (Ingala et al., 2018).

Previous studies found that Henipaviruses were the most common zoonotic pathogens in natural reservoir hosts, Pteropus species (Mackenzie, Field, \& Guyatt, 2003; Daszak et al., 2006), while bacterial communities associated with dietary habits of bats were less explored (Philips et al., 2012). Their role of microbiome in disease epidemiology is important as bats are prone to a variety of microorganisms including viruses, bacteria, fungi, and parasites (Whitaker, Ritzi, \& Dick, 2009; Wibbelt, Speck, \& Field, 2009). However, microbiota composition in 1,411 species of bats (Wilson \& Mittermeier, 2019) has not been well studied, and thus should be explored in order to understand bats' microbiome from various aspects including host-microbe relationships (Daniel et al., 2013; Banskar, Bhute, Suryavanshi, Punekar, \& Shouche, 2016b). Similarly, Banksar et al., (2016b) reported that bats carry potential bacterial pathogens, and suggested importance of studying the effect of these pathogens on bats themselves and possible transmission to humans and other animals.

Fruits are the primary diet of bats, and influence the abundance of different types of bacteria in their intestinal tract due to the nutritionally rich environment, which provides information about the dietary habits and feeding behaviors of bats (David et al., 2014; Banskar, Mourya, \& Shouche, 2016a). Foraging habits may be critical for richness of gut bacteria and such information is necessary in determining the ecological significance of the hosts (Mühldorfer, 2013; Daniel et al., 2013). In addition, a report by Sharon et al., (2010) suggested that gut microbes not only affect host physiology but also affect their evolution.

We focused on bacterial $16 S$ rRNA gene of mitochondrial DNA (mtDNA) as the substitution rate is high, making this locus valuable for distinguishing organisms, especially among closely related species (Hillis \& Dixon, 1991; Long \& Dawid, 1980; Osorio, Collins, Romalde, \& Toranzo, 2005). Further, metagenomic studies using $16 S$ rRNA gene have been widely used to characterize gut microbial communities in wildlife such as bats, primates, tigers, and birds (Carrillo-Araujo et al., 2015; Chen et al., 2018; Garcia-Mazcorro et al., 2017; Philips et al., 2012). It has been shown that two variant regions in 16SrRNA gene, namely V3 and V4, provide sufficient phylogenetic information on bacteria (Huse et al., 2008; Liu, Lozupone, Hamady, Bushman, \& Knight, 2007). For example, by using the culture-based approach, researchers have used this gene to identify bacterial species in intestine of the bat Cynopterus brachyotis, providing more detailed information than previous studies at only the genus level (Daniel et al., 2013).

As information on the distribution and diversity of microbes found in pteropodids from the Indomalaya region is limited (Daniel et al., 2013), the present study focuses on identification and screening of the bacterial communities from bats' intestine samples using next-generation sequencing (NGS). The results provide an overview of bacteria isolated from bats with a particular emphasis on major bacterial pathogens that have the potential to cause disease in bats and humans. In addition, dietary habits and geographical locations of island flying fox have been discussed as factors affecting their potential as vectors of pathogenic bacteria.

\section{Materials and Methods}

\section{Study area}

In Peninsular Malaysia, we sampled P. hypomelanus at four sites, including Dangli Island (Langkawi), Pantai Teluk Nipah in Pangkor Island (Perak), Mat Kepit in Redang Island (Terengganu), and Tanjung Balang in Tinggi Island (Johor) (Figure 1). 


\section{Langkawi Island}

Dangli Island is a small island to the north of Langkawi Island. The uninhabited island is visible from the beach at Tanjung Rhu. It is within a small group of islets that include Gasing Island and Pasir Island. $P$. hypomelanus can be found roosting in the trees on the two rocky outcrops on Dangli Island in the north and Lalang Island to the south of Langkawi archipelago. This island is classified as the most environmentally diverse among all sites. Its inland is mountainous and covered with mixed dipterocarp forest.

\section{Pangkor Island}

An island located in the Strait of Malacca on the west coast of Peninsular Malaysia between $04^{\circ} 13.0^{\prime} \mathrm{N}$ latitude and $100^{\circ} 33.0^{\prime} \mathrm{E}$ longitude. It is one of the most famous islands in Malaysia, $3.5 \mathrm{~km}$ from Peninsular Malaysia with land area of $18 \mathrm{~km}^{2}$. This island is classified as coastal hill forest with high conservation. The highest point is Bukit Pangkor at 371 meters above sea level. It has a population of approximately 25,000 and the major industries of the island are tourism and fishing.

\section{Redang Island}

Redang Island is an island in Kuala Nerus District, Terengganu, Malaysia. It is one of the largest islands off the east coast of Peninsular Malaysia, which lies about $45 \mathrm{~km}$ from the coast of Terengganu state. Pulau Redang measures about $7 \mathrm{~km}$ long and $6 \mathrm{~km}$ wide. Its highest peak is Bukit Besar at 359 meters above sea level. It has an equatorial climate with high temperatures throughout the year, ranging from $22^{\circ} \mathrm{C}$ in the early morning to $34^{\circ} \mathrm{C}$ at noon. This island is an important conservation site for sea turtles.

\section{Tinggi Island}

Tinggi Island is located $37 \mathrm{~km}$ southeast of Mersing, on the east coast of Johor with land area of $15 \mathrm{~km}^{2}$. It rises 600 meters above sea level. It takes approximately 45 minutes to reach Tinggi Island by boat from mainland. The inland is mostly covered by secondary lowland Dipterocarp rainforest. It has fresh water, fruits, rattan, and timber. A sheltered harbor with coral reefs abounds with prolific marine life. It has a long coastline with white sandy beaches and caves. This island has the highest residential population among the east coast Johor islands, with the latest tally estimated at only 448 people, from three villages including Kampung Tanjung Balang, Kampung Pasir Panjang, and Kampung Sebirah Besar.

\section{Sample collection}

A total of eight samples were collected and used in this microbiome analysis (Table 1). The island flying foxes were captured and dissected with proper biosafety equipment in laboratories, and a portion of the intestine content was collected (Daniel et al., 2013). The intestinal content was removed using the forceps and swabs before total DNA extraction (Figure 2).

\section{DNA extraction and 16S rRNA gene amplification}

Bacterial genomic DNA extraction was carried out using innuPREP Stool DNA Kit (Analytik Jena, Germany). The purity and concentration of DNA were confirmed by both spectrophotometric and fluorometric methods using Implen Nanophotometer and Qubit 4.0 HS Assay Kit (Life Technologies), respectively. Two rounds of polymerase chain reaction (PCR) were performed. The first PCR is amplification of the targeted locus of 16S rRNA gene. The second PCR is for indexing of purified PCR products. 16S rRNA gene was amplified by PCR using primers targeting the V3 and V4 regions. Following are the universal bacterial primer pair F515 (5'-TCGTCGGCAGCGTCAGATGTGTATAAGAGACAG GTGCCAGCMGCCGCGGTAA-3') and R806 (5'-GTCTCGTGGGCTCGGAGATGTGTATAAGAGACAG GGACTACHVGGGTWTCTAAT3') with Illumina adapter overhang sequences (underlined) (Ramadan, Solyman, Taha, \& Hanora, 2016; Tawfik, Azab, Ahmed, \& Fayyad, 2018). A total volume of $25 \mu \mathrm{L}$ PCR mixture was prepared for each sample consisting of $12.5 \mathrm{uL}$ of $2 \times$ KAPA HiFi Hotstart ReadyMix (KAPA Biosystems, Wilmington MA, USA), $5 \mathrm{uL}$ each of $10 \mu \mathrm{M}$ forward and reverse primers and $2.5 \mu \mathrm{L}$ of template DNA. The PCR reaction was performed on Alpha Cycler 1 PCRmax with the following protocol: initial denaturation for 3 min at $95^{\circ} \mathrm{C}$, 35 cycles of $30 \mathrm{~s}$ at $95^{\circ} \mathrm{C}, 30 \mathrm{~s}$ at $55^{\circ} \mathrm{C}$, and $30 \mathrm{~s}$ at $72^{\circ} \mathrm{C}$, with a final elongation at $72^{\circ} \mathrm{C}$ for $5 \mathrm{~min}$. The 
PCR products were purified using 0.7X volume ratio of Kapa pure beads (KAPA Biosystems, USA). Then, the second PCR was conducted for indexing amplicons from the first PCR using Nextera XT Index Kit v2 (Illumina Inc, USA). $5 \mu \mathrm{L}$ of Index 1 and Index 2 primers were added to $1 \mu \mathrm{L}$ of purified PCR product and $12.5 \mu \mathrm{L}$ of $2 \times$ KAPA HiFi Hotstart ReadyMix. Optimized PCR conditions for 12 cycles are as follow: polymerase activation for $3 \mathrm{~min}$ at $72^{\circ} \mathrm{C}$, initial denaturation for $30 \mathrm{~s} \mathrm{at} 95^{\circ} \mathrm{C}, 12$ cycles of denaturation for $10 \mathrm{~s}$ at $95^{\circ} \mathrm{C}, 30 \mathrm{~s}$ at $55^{\circ} \mathrm{C}$, and $30 \mathrm{~s}$ at $72^{\circ} \mathrm{C}$, and a final elongation at $72^{\circ} \mathrm{C}$ for $5 \mathrm{~min}$. The PCR products were examined by electrophoresis using $1.5 \%$ agarose gel in $1 \mathrm{X}$ TAE buffer. Next, sizes of PCR amplicons were analyzed using LabChip@ $\mathrm{BX}$ Touch, and a representative result from the E-gram with a clear peak at $652 \mathrm{bp}$ is shown (Figure 3 ).

\section{Quantification and NGS}

The purified amplicons containing the full-length Illumina adapters and unique barcodes were quantified

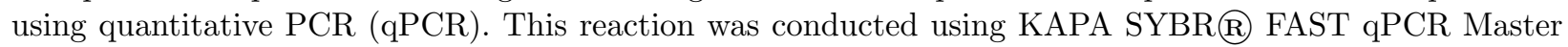
Mix (KAPA Biosystems, USA). A total volume of $20 \mu \mathrm{L}$ PCR mixture was prepared that contains $10 \mu \mathrm{L}$ KAPA SYBR@ FAST qPCR Master Mix, $2 \mu \mathrm{L}$ primer premix, $4 \mu \mathrm{L}$ indexed-amplicon, and $4 \mu \mathrm{L}$ RNase-free distilled water. The PCR reaction was performed on a Eco48 Real Time PCR system (PCRmax) under the following condition: $95^{\circ} \mathrm{C}$ for $5 \mathrm{~min}$, followed by 25 cycles of $95^{\circ} \mathrm{C}$ for $40 \mathrm{sec}, 60$ for $2 \mathrm{~min}, 72 \mathrm{degC}$ for 1 $\mathrm{min}$, and a final extension step at $72 \operatorname{deg} \mathrm{C}$ for $7 \mathrm{~min}$. Normalization is crucial for the success of sequencing, which equalizes the concentration of DNA libraries for multiplexing in order to obtain similar number of reads from each sample. Based on the qPCR and Qubit quantification data, the amplicons were normalized and pooled into a single library for NGS. The multiplexed library consists of $300 \mu \mathrm{L}$ pooled amplicons $(1.3$ pM) and $200 \mu \mathrm{L}$ PhiX Control kit (1.3 pM). The sequencing length is $2 \times 151$ cycles using a MiniSeq High Throughput Reagent Kit on an Illumina Miniseq platform (Illumina Inc, USA), Sequencing was conducted at Evolutionary and Conservation Genetics Laboratory of Department of Technology and Natural Resources, Universiti Tun Hussein Onn Malaysia.

\section{Sequencing data, Bioinformatic and Statistical Analyses}

Quality filtering and demultiplexing of generated sequences were performed using CLC Genomic Workbench software (CLC) (Qiagen, USA). An initial assessment of quality scores of the sequencing data was conducted on FASTQ files. Aligned sequences were then clustered into operational taxonomic unit (OTUs) defined by 97\% similarity and OTUs were aligned using MUSCLE tool in CLC. Rarefaction curves were then plotted with the OTUs observed with a given sequencing depth using CLC. OTUs were given taxonomic assignment using Greengenes database with the confidence threshold of 97\% (Amato et al., 2013) and these trees were used for the calculation of alpha diversity indices (Chao1, Shannon, Simpson, and Evenness) in all samples from each island population as described in the PAST 3 software (Hammer, Harper, \& Ryan, 2001). Beta diversity (weighted UniFrac distance) metrics were calculated to describe the dissimilarities by considering both the evolutionary distances and the frequency of occurrences of bacterial phylotypes observed among populations (Philips et al., 2012). Principal coordinate analysis (PCoA) was illustrated based on the UniFrac distances to portray the relationship among populations, and Venn diagram was generated to show the number of unique and shared OTUs among the populations at the $97 \%$ similarity. Based on the Bray-Curtis measurements, phylogenetic dendrogram and heatmap were generated with the 1000 of bootstraps and weighted pair clustering, respectively. The phylogenetic relationships of the microbiome community between populations estimated from this analysis were compared to the host phylogeny presented in Mohd-Yusof, Senawi, Rovie-Ryan, Nor, and Md-Zain, (2019). Host phylogeny tree which is distancebased, Neighbor-Joining was performed by using MEGA7 (Tamura, Stecher, Peterson, Filipski, \& Kumar, 2013). The correlation of microbial diversity (genera) among the populations was then measured using the Pearson correlation coefficient with a significance threshold of $p<0.05$ using PAST 3 software, supported by generation of cold-hot plot figure.

\section{Results}

A total of 30,404 sequences in bacterial 16S rRNA gene OTUs were identified, ranging from 16,540 to 2,149 
sequences. At the $97 \%$ similarity cut-off, 166 different OTUs were produced, ranging from 35 to 131 OTUs for each sample. The alpha diversity index of OTUs observed in island populations ranges from 1.001 to $3.065,0.4684$ to 0.8921 , and 35.13 to 132.8 of richness estimated by Shannon $H$, Simpson 1-D and Chao1, respectively (Table 2). Based on the Shannon and Simpson diversity indices, Redang Island showed the highest diversity of OTUs $(H=3.065,1-\mathrm{D}=0.8921)$, followed by Pangkor Island $(H=2.28,1-\mathrm{D}=$ $0.8279)$, Tinggi Island $(H=1.202,1-\mathrm{D}=0.4633)$, and Langkawi Island $(H=1.001,1-\mathrm{D}=0.4684)$ (Table 2 ). Similar findings were observed in rarefaction analysis of OTUs from each population (Figure 4). Three island populations revealed increasing rarefaction curves which indicate the bacterial richness analysis was complete without being biased by the number of sequences analyzed. However, samples from Pangkor Island exhibited lower sequencing depth than other populations.

The OTUs were successfully aligned to 7 phyla, 54 families, 82 genera, and 88 species. The relative abundance of various microbial taxa differed significantly among populations. OTUs from the phyla Proteobacteria and Firmicutes dominated all four populations (Proteobacteria average relative abundance $=54.1 \%$; Firmicutes average relative abundance $=41.1 \%)$. Additional phyla were found in relatively low abundance, including Actinobacteria (2.9\%), Bacteroidetes (1.2\%), and Acidobacteria, Fusobacteria, and Chloroflexi phyla (less than $0.5 \%$ ) (Table 3). Phylum Proteobacteria are mostly found in 3 islands, Pangkor Island (92.18\%), Tinggi Island (89.24\%), Redang Island (74.74\%), while phylum Firmicutes is the highest in Langkawi Island (69.39\%) (Figure 5). Additionally, at the family level, Streptococcaceae (39.34\%), Enterobacteriaceae (23.64\%), and Pseudomonadaceae (22.88\%) were the top 3 largest bacterial groups, compared to other families which were below $5 \%$ (Table 4). However, a large proportion of bacterial sequences could not be assigned to any known families including several unknown families representing less than $5 \%$ of the total OTUs sequences (Figure 6 ). The 30 most predominant genera were analyzed by hierarchical clustering to evaluate the relationship between four populations of $P$. hypomelanus, and results were shown in gradient heatmap with dendrogram at the genus level (Figure 7).

Based on Venn diagram in Figure 8, seven bacterial OTUs were shared among four populations. Redang Island has 131 OTUs with unique sequences, largest among all populations, followed by Langkawi Island (63), Pangkor Island (49), and Tinggi Island (35). To understand the relationships among different populations, we generated phylogenetic dendrogram based on Bray-Curtis distances, which revealed that the populations from Langkawi Island and Redang Island were closely related in the gut microbiome communities while the bacteria groups in the Pangkor Island was found to be closely related to those in Tinggi Island. However, this bacterial phylogeny among four populations demonstrates a different topology from that of the host phylogenetic tree which shows separation between north-west and east-south groups (Figure 9). This comparison reveals the extent of congruency between phylogenetic relationships among gut microbiomes and those among the hosts. Similarly, based on UniFrac distances, Redang and Langkawi Islands clustered closely in PCoA analysis, indicating similar bacteria community patterns between two populations (Figure 10).

\section{Correlation and Significance of Relationships between Populations}

In order to obtain correlation among bacterial communities (genera), the Pearson's correlation analysis was performed between four populations from Langkawi Island, Pangkor Island, Redang Island, and Tinggi Island. The results showed the strongest correlation $(\mathrm{p}<0.05)$ between Pangkor Island and Tinggi Island $(\mathrm{r}=0.31, \mathrm{p}<0.05)$, followed by Redang Island and Langkawi Island $(\mathrm{r}=0.26, \mathrm{p}<0.05)$ (Table 5). Furthermore, by cold-hot plot, the strength of correlation between populations was scaled to a range from -1 to 1. Langkawi Island-Redang Island and Pangkor Island-Tinggi Island have strong correlation as their $\mathrm{r}$ value is close to 1 (Figure 11).

\section{Discussion}

\section{Diversity and Abundance of Gut Microbiome of P. hypomelanus}

Island flying fox is of particular interest to researchers because bats are a group of volant mammals that have unique evolutionary adaptation to habitats. Recently, high-throughput sequencing technology has become available and provided an efficient tool for analyzing the relationships between microorganisms that are 
thought to influence their species diversity and functions (Philips et al., 2012). The purpose of the current study was to provide the first documentation on gut microbiome in $P$. hypomelanus from different island populations in Peninsular Malaysia.

In this study, we acquired data from bacteria in 7 phyla, 54 families, and 82 genera. This highlights the advantages of using high-throughput sequencing compared to culture-based approaches in studying bacterial communities (Wang et al., 2014; Wang et al., 2015). We observed that Proteobacteria and Firmicutes phyla are predominant, confirming the stable nature of these phyla in bat gut environment from all populations. However, these same bacterial classes have also been observed in the intestinal microbiotas of other mammals such as primates, buffalo and camel (Banskar et al., 2016b; Bhatt, Dande, Patil, \& Joshi, 2013; Ochman et al., 2010; Patel et al., 2014; Swanson et al., 2011). This suggests that these specific bacteria groups are especially well adapted to the environment in mammals' intestine.

Moreover, three families of gut bacteria (Enterobacteriaceae, Pseudomonadaceae, and Rhodobacteraceae) were most abundant in the Proteobacteria group. These bacterial families are facultative anaerobes and function in glucose fermentation (Banskar et al., 2016a). According to Starr and Chatterje (1972), the genus Erwinia in the family Enterobacteriaceae has been identified in pathogenic plants. In particular, presence of Erwinia in fruit bats indicates that the bats have acquired it through contaminated fruits or leaves (Banskar et al., 2016a). In contrast, samples from Langkawi Island show a large percentage of Firmicutes ( $70 \%)$, with family Streptococcaceae being the most dominant compared to other populations. Bacterial phyla including Firmicutes have been associated with digestion of diets rich in fiber and fermentable carbohydrates (Carrillo-Araujo et al., 2015; Chen et al., 2017). According to Carrillo-Araujo et al., (2015), the effects of bacterial phyla Firmicutes on the ecology and physiology of wildlife are not well-understood. Thus it would be very important to understand the implications of these bacteria in metabolism of their hosts with high carbohydrate intake.

The general composition of gut microbiota in bats is strikingly different from that of other mammalian gut microbiomes, which are generally dominated by Firmicutes. Interestingly, the relatively high abundance of Proteobacteria in the chiropteran gut is similar to that found in the avian gut, suggesting the convergence of microbiomes in flying vertebrates (Hird, Sanchez, Carstens, \& Brumfield, 2015). Regardless of diet, the distal gut of bats is dominated by bacteria in the family Enterobacteriaceae (phylum Proteobacteria), although fruit bats hosted larger amount of Clostridiaceae (phylum Firmicutes) and Streptococcaceae (phylum Firmicutes) than insectivorous bats, a finding previously observed in Neotropical bats (Phillips et al., 2012). Many bacterial species in the Lactobacillales are found on fermenting fruits (Endo et al., 2018; Splittstoesser, 1982), thus the presence of Streptococcaceae (order Lactobacillales) in the fruit bat gut may be due to ingestion rather than established residence, a possibility that requires further investigation.

From 82 genera isolated from intestinal content of flying fox, we found a common presence of potentially pathogenic microbes, includingPseudomonas, Corynebacterium, Staphylococcus, Enterococcus, Streptococcus , and Clostridium. Previous studies have reported a similar bacteria genus associated with bats, although some genera were not isolated from this study (Anand \& Sripathi, 2004; Chaverri, 2006; Di Bella et al., 2003; Graves et al., 1988; Heard, De Young, Goodyear, \& Ellis, 1997; Klite, 1965; Mühldorfer et al., 2010; Whitaker, Dannelly, \& Prentice, 2004). This could be due to the limited number of bacterial isolates, the small sample size used, or the phylogenetics of the host itself (Warren \& Witter, 2002). Meanwhile, the generaEnterobacter, Pseudomonas, Serratia, and Klebsiellaisolated in this study were previously found in the rectum of other fruit bats, such as Cynopterus bracyhotis (Daniel et al., 2013; Graves et al., 1988). Most gut microbiota in mammals play a role in breaking down carbohydrates into short fatty acid chains (acetate, propionate, and butyrate) which provide energy and nutrients for the organisms. (Caroline, Gross, \& Spillman, 2003; Macfarlane \& Macfarlane, 2003; Samuel et al., 2008). For example, Enterobacter breaks down most sugars including xylose, which is one of the most abundant components in plants (Rastall, 2004). Besides, Serratia and Klebsiellaare also known to exhibit cellulolytic properties (Anand \& Sripathi, 2004).

Comparison of Diversity and Abundance of Gut Microbiome of P. hypomelanus between Islands in Peninsular Malaysia 
The results of our metagenomic analysis showed that the bacterial communities in $P$. hypomelanus were diverse with little variation in species composition and proportion among different island populations. Overall, the population from Redang Island has relatively high abundance of gut microbiome compared to other populations. Meanwhile, the population from Tinggi Island has a lower diversity index ( $\left.\mathrm{H}^{\prime}\right)$ of gut microbiome compared to other populations. Low bacterial diversity is associated with poor physical fitness while high diversity indicates good health (Scott, Jean-Michel, Midtvedt, \& Van Hemert, 2015). In addition, populations from Tinggi Island and Pangkor Island have higher abundance of Proteobacteria than the other populations, at $92.18 \%$ and $89.24 \%$, respectively. According to Carvalho et al., (2012), high abundance of Proteobacteria indicates that the population has the potential to become infected.

Langkawi Island, located in Kedah, has a land area of $328 \mathrm{~km}^{2}$, while Redang Island in Terengganu is 42 $\mathrm{km}^{2}$, Pangkor Island in Perak is $18 \mathrm{~km}^{2}$, and Tinggi Island in Johor is $15 \mathrm{~km}^{2}$. In this study, we tested the hypothesis that flying fox occupying islands with different habitat quality and environment may develop different gut microbiome. Langkawi and Redang Islands have larger island size compared to Pangkor Island and Tinggi Island. According to MacArthur and Wilson (1967), the size of islands strongly influences rate of extinction, as large islands tend to have higher immigration rates than small islands. Therefore, large islands tend to have lower extinction rate because they usually have more food resources and more diverse habitats for residential species. Therefore, animals occupying large areas of habitats consumed more diverse diets and consequently sustain higher gut microbiome richness and diversity (Amato et al., 2013).

Residential populations around the island indirectly affect the abundance and diversity of gut microbiome of $P$. hypomelanus . Sampling areas in Langkawi Island and Redang Island were better protected from interference by human compared to those in Pangkor Island and Tinggi Island. Besides, Tinggi Island comprises three villages, namely Kampung Tanjung Balang, Kampung Pasir Panjang, and Kampung Sebirah Besar, with a large number of residents. Habitats with high population density and scarce food sources may affect the diet of $P$. hypomelanus on the island. As a result, their diets deviate from the typical dietary habits, which can be associated with shifts in microbiome composition. In general, animals in disturbed habitats consume different types of food from animals in less disturbed areas (Abbas et al., 2011; Chaves, Stoner, \& Arroyo-Rodriguez, 2012; Flaherty, Ben-David, \& Smith, 2010; Kamler, Ballard, Wallace, \& Gipson, 2007). Moreover, inhabiting disturbed habitats may lead to dysbiosis, such as lower microbial richness and diversity that may affect host nutrition and health (Stumpf et al., 2016). Overall, gut microbiome can affect hosts by altering fat storage during food scarcity and environmental changes (David et al., 2014; Faith, McNulty, Rey, \& Gordon, 2011; Turnbaugh et al., 2006). Results from this study suggest that the diet of flying fox in minimally disturbed habitats in Langkawi and Redang Islands appears to promote the acquisition and maintenance of a diverse gut microbiome.

The gut microbiomes in the populations of Langkawi Island and Redang Island were found to be closely related, as there were no significant differences in bacterial diversity of the gut microbiota. Similarly, dendrogram from cluster analysis supports the segregation of gut microbiomes between the populations (Langkawi-Redang) and (Pangkor-Tinggi). However, the relationships between the bacterial communities result in a topology opposed to the well-supported host phylogeny (Mohd-Yusof et al., 2019). Phylogenetic relationships of $P$. hypomelanus based on Cytochrome $b$ DNA sequence have been characterized in the recent study by Mohd-Yusof et al., (2019). Their study showed the separation of P. hypomelanus populations between the north-west (Langkawi-Pangkor) and south-east (Redang-Tinggi) groups based on genetic data. In addition, the population of a subspecies, P. h. robinsoni, in north-west of Peninsular Malaysia was found to be monophyletic in phylogenetic analysis without sharing haplotypes with $P$. $h$. lepidus from south-east region (Mohd-Yusof, Senawi, Nor, \& Md-Zain, 2020). Our findings differ markedly from studies of all other mammals, which showed phylogenetic relatedness among hosts is significantly correlated with similarity among microbial communities (Ley et al., 2008; Moeller et al., 2016; Moeller et al., 2017; Sanders et al., 2017). Nevertheless, our results are consistent with the previous report that microbial community are driven by shared ecological features such as locality and elevation rather than the host phylogeny (Nishida \& Ochman, 2018). 
As suggested in previous studies on flying vertebrates (bats and birds), convergent adaptations driven by flight may influence digestive physiology, such as increasing paracellular absorption and accelerating the transit time of food through the gut (Canals, Iriarte-Diaz, \& Grossi, 2011; Caviedes-Vidal et al., 2007; Caviedes-Vidal et al., 2008; Price, Brun, Caviedes-Vidal, \& Karasov, 2015). These physiological adaptations to flight may in turn affect the nature and composition of microbial communities in flying vertebrates, providing an explanation for the absence of a phylogenetic correlation between bats and their microbes. Moreover, flying is an energetically demanding form of locomotion that requires the animal to have a small size of gut. Compared to other non-flying mammals, bats have relatively smaller gastrointestinal (GI) tracts and reduced intestinal tissue which can help to minimize flight mass (Caviedes-Vidal et al., 2007; CaviedesVidal et al., 2008; Forman, 1990; Strobel, Encarnação, Becker, \& Trenczek, 2015). Recent study by Lutz et al., (2019) also reported that energetic demands of flight place significant constraints on gut physiology, which in turn restricts the microbial community in the gut, resulting in the absence of correlation between host phylogeny and microbiome composition.

Taken together, these factors have shaped the structure of the data, which revealed bacterial communities between island populations at larger spatial scales in Peninsular Malaysia. Our results revealed important mechanisms that are critical for improving our knowledge of host-microbe interactions in island flying fox populations. This information will serve as a basis for conservation efforts and better assessment of the impact of human activity on animal health and zoonotic disease managements. However, future research is needed to identify specific plant taxa in the diet of $P$. hypomelanus at finer geographic scales to help promote healthy gut microbiome in $P$. hypomelanus in Peninsular Malaysia.

\section{Conclusion}

In conclusion, we have outlined the diversity and distribution of bacteria isolated from gut of island flying fox across four populations in Peninsular Malaysia. Given that collection localities were separated by geographical distance and differ in island size, an unexpected observation from this study was that environment of island populations apparently influences gut microbiome. We did not find a significant correlation between the host phylogenetic relationship and microbial community similarity, suggesting the microbiota observed in bats is not driven by host evolution, but rather by ecological features.

\section{Authors' Contributions}

N.S.M.Y., M.A.B.A.L., A.R.M.R., and B.M.M.Z. designed the project. N.S.M.Y. involved in field sample collection. N.S.M.Y., M.A.B.A.L., A.R.M.R., and A.S.B performed the laboratory work. N.S.M.Y., M.A.B.A.L., A.R.M.R. wrote the manuscript and analyzed and interpreted the data. S.Y., S.M.N., M.A.B.A.L., B.M.M.Z. edited the manuscript. All authors read and approved the last version of the manuscript.

\section{Acknowledgements}

The authors are deeply indebted to Department of Wildlife and National Parks Peninsular Malaysia for providing research permit: JPHLandTN(IP):100-6/1/14(39). The authors acknowledge Universiti Kebangsaan Malaysia and Universiti Tun Hussein Onn Malaysia, for providing necessary funding, facilities, and assistance. We appreciated Dr Juliana Senawi and UKM students for their contribution during field genetic samplings.

\section{Funding}

Funding for this project was provided by Grants AP-2015-004, GUP-2019-037, GUP-2011-183, ST-2017-007, FRGS/1/2018/WAB13/UTHM/03/2 and MTUN-UTHM-K121 by Ministry of Education Malaysia.

\section{Conflict of Interest Statement}

None declared.

\section{Statement of Data Accessibility}


We will submit the dataset for microbiome sequence presented in this study to EMBL-EBI database. Due to covid19 outbreak and lockdown in Malaysia, we are currently unable to access our sequence DATA in the lab. However, we plan to submit this data during review process and expect to make the data available online prior to publication. We also agree to make this as one of the prerequisite if the manuscript is accepted.

\section{References}

Abbas, F., Morellet, N., Hewison, A. M., Merlet, J., Cargnelutti, B., Lourtet, B., .. Verheyden, H. (2011). Landscape fragmentation generates spatial variation of diet composition and quality in a generalist herbivore. Oecologia , 167 , 401-411. https://doi.org/10.1007/s00442-011-1994-0

Amato, K. R., Yeoman, C. J., Kent, A., Righini, N., Carbonero, F., Estrada, A., .. Gillis, M. (2013). Habitat degradation impacts black howler monkey (Alouatta pigra) gastrointestinal microbiomes. ISME Journal, 7 , 1344-1353. https://doi.org/10.1038/ismej.2013.16

Anand, A. A. P., \& Sripathi, K. (2004). Digestion of cellulose and xylan by symbiotic bacteria in the intestine of the Indian flying fox (Pteropus giganteus ). Comparative Biochemistry and Physiology Part A: Molecular and Integrative Physiology , 139 , 65-69. https://doi.org/10.1016/j.cbpb.2004.07.006

Armougom, F., \& Raoult, D. (2009). Exploring microbial diversity using 16S rRNA high-throughput methods. Journal of Computers Science and Systems Biology , 2 , 74-92. http://doi.org/10.4172/jcsb.1000019

Aziz, S. A., Clements, G. R., McConkey, K. R., Sritongchuay, T., Pathil, S., Abu Yazid, M. N. H., ... Bumrungsri, S. (2017a). Pollination by the locally endangered island flying fox (Pteropus hypomelanus ) enhances fruit production of the economically important durian (Durio zibethinus). Ecology and Evolution , 7, 8670-8684. https://doi.org/10.1002/ece3.3213

Aziz, S. A., Clements, G. R., Peng, L. Y., Campos-Arceiz, A., McConkey, K. R., Forget, P. M., \& Gan, H. M. (2017b). Elucidating the diet of the island flying fox (Pteropus hypomelanus ) in Peninsular Malaysia through Illumina Next-Generation Sequencing. PeerJ, 5 , e3176. https://doi.org/10.7717/peerj.3176

Banskar, S., Mourya, D. T., \& Shouche, Y. S. (2016a). Bacterial diversity indicates dietary overlap among bats of different feeding habits. Microbiological Research , 182 , 99-108. https://doi.org/10.1016/j.micres.2015.10.006

Banskar, S., Bhute, S. S., Suryavanshi, M. V., Punekar, S., \& Shouche, Y. S. (2016b). Microbiome analysis reveals the abundance of bacterial pathogens in Rousettus leschenaultii guano. Scientific Reports , 6 , 1-13. https://doi.org/10.1038/srep36948

Bhatt, V. D., Dande, S. S., Patil, N. V., \& Joshi, C. G. (2013). Molecular analysis of the bacterial microbiome in the forestomach fluid from the dromedary camel (Camelus dromedarius ). Molecular Biology Reports , 40 , 3363-3371. https://doi.org/10.1007/s11033-012-2411-4

Buffie, C. G., \& Pamer, E. G. (2013). Microbiota-mediated colonization resistance against intestinal pathogens. Nature Reviews Immunology , 13 , 790-801. https://doi.org/10.1038/nri3535

Canals, L. M., Iriarte-Diaz, J., \& Grossi, B. (2011). Biomechanical, respiratory and cardiovascular adaptations of bats and the case of the small community of bats in Chile. In Kliva, V. (Ed.), Biomechanics in Applications (pp. 299-322). London, UK: IntechOpen.

Caroline, J., Gross, M. S., \& Spillman, D. M. (2003). Fiber digestion in mammals. Pakistan Journal of Biological Science , 6, 1564-1573.

Carrillo-Araujo, M., Taş, N., Alcantara-Hernandez, R. J., Gaona, O., Schondube, J. E., Medellin, R. A., ... Falcon, L. I. (2015). Phyllostomid bat microbiome composition is associated to host phylogeny and feeding strategies. Frontiers in Microbiology , 6 , 1-9. https://doi.org/10.3389/fmicb.2015.00447

Caviedes-Vidal, E., McWhorter, T. J., Lavin, S. R., Chediack, J. G., Tracy, C. R., \& Karasov, W. H. (2007). The digestive adaptation of flying vertebrates: high intestinal paracellular absorption compensates 
for smaller guts. Proceedings of the National Academy of Sciences of the United States of America, 104, 19132-19137. https://doi.org/10.1073/pnas.0703159104

Caviedes-Vidal, E., Karasov, W. H., Chediack, J. G., Fasulo, V., Cruz-Neto, A. P., \& Otani, L. (2008). Paracellular absorption: a bat breaks the mammal paradigm. PLoS One , 3 , e1425. https://dx.doi.org/10.1371\%2Fjournal.pone.0001425

Cui, J., Li, F., \& Shi, Z. L. (2019). Origin and evolution of pathogenic coronaviruses. Nature Reviews Microbiology , 17 , 181-192. https://doi.org/10.1038/s41579-018-0118-9

Chaverri, G. (2006). Aerobic bacterial flora from the digestive tract of the common vampire bat, Desmodus rotundus (Chiroptera: Phyllostomidae). Revista de Biologia Tropical , 54 , 717-724.

Chaves, O. M., Stoner, K. E., \& Arroyo-Rodríguez, V. (2012). Differences in diet between spider monkey groups living in forest fragments and continuous forest in Mexico. Biotropica , 44 , 105-113. https://doi.org/10.1111/j.1744-7429.2011.00766.x

Chen, X., Li, Q. Y., Li, G. D., Xu, F. J., Han, L., Jiang, Y., ... Jiang, C. L. (2018). The distal gut bacterial community of some primates and carnivora. Current Microbiology , 75 , 213-222. https://doi.org/10.1007/s00284-017-1368-x

Daniel, D. S., Ng, Y. K., Chua, E. L., Arumugam, Y., Wong, W. L., \& Kumaran, J. V. (2013). Isolation and identification of gastrointestinal microbiota from the short-nosed fruit bat Cynopterus brachyotis brachyotis . Microbiological Research , 168 , 485-496. https://doi.org/10.1016/j.micres.2013.04.001

Daszak, P., Plowright, R., Epstein, J. H., Pulliam, J., Abdul Rahman, S., Field, H. E., .. Halpin, K. (2006). The emergence of Nipah and Hendra virus: pathogen dynamics across a wildlife-livestock-human continuum. In Collinge, S. K. \& Ray, C. (Eds.), Disease Ecology: Community Structure and Pathogen Dynamics (pp. 186-201). New York: Oxford University Press.

David, L. A., Maurice, C. F., Carmody, R. N., Gootenberg, D. B., Button, J. E., Wolfe, B. E., ... Biddinger, S. B. (2014). Diet rapidly and reproducibly alters the human gut microbiome. Nature , 505 , 559-563. https://doi.org/10.1038/nature12820

Di Bella, C., Piraino, C., Caracappa, S., Fornasari, L., Violani, C., \& Zava, B. (2014). Enteric microflora in Italian Chiroptera. Journal of Mountain Ecology , 7 , 221-224.

Endo, A., Maeno, S., Tanizawa, Y., Kneifel, W., Arita, M., Dicks, L., \& Salminen, S. (2018). Fructophilic lactic acid bacteria, a unique group of fructose-fermenting microbes. Applied and Environmental Microbiology , 84, e01290-18. http://doi.org/10.1128/aem.01290-18

Faith, J. J., McNulty, N. P., Rey, F. E., \& Gordon, J. I. (2011). Predicting a human gut microbiota's response to diet in gnotobiotic mice. Science, 333 , 101-104. https://doi.org/10.1126/science.1206025

Flaherty, E. A., Ben-David, M., \& Smith, W. P. (2010). Diet and food availability: implications for foraging and dispersal of Prince of Wales northern flying squirrels across managed landscapes. Journal of Mammalogy , $91,79-91$. https://doi.org/10.1644/09-MAMM-A-014R.1

Forman, G. L. (1990). Comparative macro-and micro-anatomy of stomachs of macroglossine bats (Megachiroptera: Pteropodidae). Journal of Mammalogy , 71 , 555-565. https://doi.org/10.2307/1381794

Garcia-Mazcorro, J. F., Castillo-Carranza, S. A., Guard, B., Gomez-Vazquez, J. P., Dowd, S. E., \& Brigthsmith, D. J. (2017). Comprehensive molecular characterization of bacterial communities in feces of pet birds using 16S marker sequencing. Microbial Ecology , 73 , 224-235.

Graves, S. R., Kennelly-Merrit, S. A., Tidemann, C. R., Rawlinson, P. A., Harvey, K. J., \& Thornton, I. W. B. (1988). Antibiotic-resistance patterns of enteric bacteria of wild mammals on the Krakatau Islands and West Java, Indonesia. Philosophical Transactions of the Royal Society of London. B, Biological Sciences , 322 , 339-353. https://doi.org/10.1098/rstb.1988.0129 
Hammer, O., Harper, D. A. T., \& Ryan, P. D. (2001). PAST: paleontological statistics software package for education and data analysis. Palaeontologia Electronica , 4 , 1-9.

Heard, D. J., De Young, J. L., Goodyear, B., \& Ellis, G. A. (1997). Comparative rectal bacterial flora of four species of flying fox (Pteropus sp.). Journal of Zoo and Wildlife Medicine ,28 , 471-475.

Hillis, D. M., \& Dixon, M. T. (1991). Ribosomal DNA: molecular evolution and phylogenetic inference. The Quarterly Review of Biology ,66 , 411-453. https://doi.org/10.1086/417338

Hird, S. M., Sanchez, C., Carstens, B. C., \& Brumfield, R. T. (2015). Comparative gut microbiota of 59 neotropical bird species.Frontiers in Microbiology , 6 , 1403. https://doi.org/10.3389/fmicb.2015.01403

Huse, S. M., Dethlefsen, L., Huber, J. A., Welch, D. M., Relman, D. A., \& Sogin, M. L. (2008). Exploring microbial diversity and taxonomy using SSU rRNA hypervariable tag sequencing. PLoS Genetics , 4 , e1000255. https://doi.org/10.1371/journal.pgen.1000255

Ingala, M. R., Simmons, N. B., Wultsch, C., Krampis, K., Speer, K. A., \& Perkins, S. L. (2018). Comparing microbiome sampling methods in a wild mammal: fecal and intestinal samples record different signals of host ecology, evolution. Frontiers in Microbiology , 9 , 803. https://doi.org/10.3389/fmicb.2018.00803

Kamler, J. F., Ballard, W. B., Wallace, M. C., \& Gipson, P. S. (2007). Diets of swift foxes (Vulpes velox ) in continuous and fragmented prairie in northwestern Texas. The Southwestern Naturalist,52 , 504-510. https://doi.org/10.1894/0038-4909(2007)52[504:DOSFVV]2.0.CO;2

Kingston, T., Lim, B. L., \& Akbar, Z. (2006). Bats of Krau Wildlife Reserve . Kuala Lumpur: Universiti Kebangsaan Malaysia Publishers.

Klite, P. D. (1965). Intestinal bacterial flora and transit time of three neotropical bat species. Journal of Bacteriology ,90 , 375-379.

Kuzmin, I. V., Bozick, B., Guagliardo, S. A., Kunkel, R., Shak, J. R., Tong, S., \& Rupprecht, C. E. (2011). Bats, emerging infectious diseases, and the rabies paradigm revisited. Emerging Health Threats Journal, 4 , 7159. https://doi.org/10.3402/ehtj.v4i0.7159

Ley, R. E., Hamady, M., Lozupone, C., Turnbaugh, P. J., Ramey, R. R., Bircher, J. S., ... Gordon, J. I. (2008). Evolution of mammals and their gut microbes. Science , 320 , 1647-1651. https://doi.org/10.1126/science.1155725

Liu, Z., Lozupone, C., Hamady, M., Bushman, F. D., \& Knight, R. (2007). Short pyrosequencing reads suffice for accurate microbial community analysis. Nucleic Acids Research , 35 , e120. https://doi.org/10.1093/nar/gkm541

Long, E. O., \& Dawid, I. B. (1980). Repeated genes in eukaryotes.Annual Review of Biochemistry, 49 , 727-764. https://doi.org/10.1146/annurev.bi.49.070180.003455

Lutz, H. L., Jackson, E. W., Webala, P. W., Babyesiza, W. S., Peterhans, J. C. K., Demos, T. C., ... Gilbert, J. A. (2019). Ecology and Host Identity Outweigh Evolutionary History in Shaping the Bat Microbiome.mSystems , 4 , e00511-19. https://doi.org/10.1128/msystems.00511-19

MacArthur, R. H., \& Wilson, E. O. (1967). The Theory of Island Biogeography . Princeton: Princeton University Press.

Macfarlane, S., \& Macfarlane, G. T. (2003). Regulation of short-chain fatty acid production. Proceedings of the Nutrition Society ,62 , 67-72. https://doi.org/10.1079/PNS2002207

Mackenzie, J. S., Field, H. E., \& Guyatt, K. J. (2003). Managing emerging diseases borne by fruit bats (flying foxes), with particular reference to henipaviruses and Australian bat lyssavirus. Journal of Applied Microbiology , 94 , 59S-69S. https://doi.org/10.1046/j.1365-2672.94.s1.7.x 
Moeller, A. H., Caro-Quintero, A., Mjungu, D., Georgiev, A. V., Lonsdorf, E. V., Muller, M. N., ... Ochman, H. (2016). Cospeciation of gut microbiota with hominids. Science , 353 , 380-382. https://doi.org/10.1126/science.aaf3951

Moeller, A. H., Suzuki, T. A., Lin, D., Lacey, E. A., Wasser, S. K., \& Nachman, M. W. (2017). Dispersal limitation promotes the diversification of the mammalian gut microbiota. Proceedings of the National Academy of Sciences of the United States of America , 114 , 13768-13773. https://doi.org/10.1073/pnas.1700122114

Mohd-Yusof, N. S., Senawi, J., Rovie-Ryan, J. J., Nor, S. M., \& Md-Zain, B. M. (2019). Phylogenetic relationships of Island flying fox,Pteropus hypomelanus (Chiroptera: Pteropodidae) along the east and west coast of Peninsular Malaysia based on Cytochrome b sequences.AIP Conference Proceedings , 2111 , 060016. https://doi.org/10.1063/1.5111278

Mohd-Yusof, N. S., Senawi, J., Nor, S. M., \& Md-Zain, B. M. (2020). Haplotype and network analysis of island flying fox (Pteropus hypomelanus ) using D-loop region of mitochondrial DNA to confirm subspecies designation. Mammal Research , 65 , 375-385. https://doi.org/10.1007/s13364-019-00468-9

Muhldorfer, K., Wibbelt, G., Haensel, J., Riehm, J., \& Speck, S. (2010). Yersinia species isolated from bats, Germany.Emerging Infectious Diseases , 16 , 578-580. https://dx.doi.org/10.3201\%2Feid1603.091035

Muhldorfer, K. (2013). Bats and bacterial pathogens: a review.Zoonoses and Public Health , 60 , 93-103. https://doi.org/10.1111/j.1863-2378.2012.01536.x

Muscarella, R., \& Fleming, T. H. (2007). The role of frugivorous bats in tropical forest succession. Biological Reviews , 82 , 573-590. https://doi.org/10.1111/j.1469-185X.2007.00026.x

Nishida, A. H., \& Ochman, H. (2018). Rates of gut microbiome divergence in mammals. Molecular Ecology , 27, 1884-1897. https://doi.org/10.1111/mec.14473

Ochman, H., Worobey, M., Kuo, C. H., Ndjango, J. B. N., Peeters, M., Hahn, B. H., \& Hugenholtz, P. (2010). Evolutionary relationships of wild hominids recapitulated by gut microbial communities. PLoS Biology , 8 , e1000546. https://doi.org/10.1371/journal.pbio.1000546

Osorio, C. R., Collins, M. D., Romalde, J. L., \& Toranzo, A. E. (2005). Variation in 16S-23S rRNA intergenic spacer regions inPhotobacterium damselae : a mosaic-like structure. Applied and Environmental Microbiology , 71 , 636-645. https://doi.org/10.1128/aem.71.2.636-645.2005

Patel, D. D., Patel, A. K., Parmar, N. R., Shah, T. M., Patel, J. B., Pandya, P. R., \& Joshi, C. G. (2014). Microbial and Carbohydrate Active Enzyme profile of buffalo rumen metagenome and their alteration in response to variation in the diet. Gene , 545 , 88-94. https://doi.org/10.1016/j.gene.2014.05.003

Phillips, C. D., Phelan, G., Dowd, S. E., McDOnOugh, M. M., Ferguson, A. W., Delton Hanson, J., .. Baker, R. J. (2012). Microbiome analysis among bats describes influences of host phylogeny, life history, physiology and geography. Molecular Ecology , 21 , 2617-2627. https://doi.org/10.1111/j.1365294X.2012.05568.x

Price, E. R., Brun, A., Caviedes-Vidal, E., \& Karasov, W. H. (2015). Digestive adaptations of aerial lifestyles. Physiology ,30 , 69-78. https://doi.org/10.1152/physiol.00020.2014

Ramadan, M., Solyman, S., Taha, M., \& Hanora, A. (2016). Preliminary characterization of human skin microbiome in healthy Egyptian individuals. Cellular and Molecular Biology , 62 , 21-27.

Rastall, R. A. (2004). Bacteria in the gut: friends and foes and how to alter the balance. The Journal of Nutrition , 134 , 2022S-2026S. https://doi.org/10.1093/jn/134.8.2022S

Samuel, B. S., Shaito, A., Motoike, T., Rey, F. E., Backhed, F., Manchester, J. K., ... Gordon, J. I. (2008). Effects of the gut microbiota on host adiposity are modulated by the short-chain fatty-acid binding G protein-coupled receptor, Gpr41. Proceedings of the National Academy of Sciences of the United States of America ,105 , 16767-16772. https://doi.org/10.1073/pnas.0808567105 
Sanders, J. G., Beichman, A. C., Roman, J., Scott, J. J., Emerson, D., McCarthy, J. J., \& Girguis, P. R. (2015). Baleen whales host a unique gut microbiome with similarities to both carnivores and herbivores.Nature Communications , 6 , 8285. https://doi.org/10.1038/ncomms9285

Scott, K. P., Jean-Michel, A., Midtvedt, T., \& van Hemert, S. (2015). Manipulating the gut microbiota to maintain health and treat disease.Microbial Ecology in Health and Disease , 26 , 25877. https://dx.doi.org/10.3402\%2Fmehd.v26.25877

Sharon, G., Segal, D., Ringo, J. M., Hefetz, A., Zilber-Rosenberg, I., \& Rosenberg, E. (2010). Commensal bacteria play a role in mating preference of Drosophila melanogaster. Proceedings of the National Academy of Sciences of the United States of America ,107, 20051-20056. https://doi.org/10.1073/pnas.1009906107

Splittstoesser, D. F. (1982). Microorganisms involved in the spoilage of fermented fruit juices. Journal of Food Protection , 45 , 874-877. https://doi.org/10.4315/0362-028X-45.9.874

Strobel, S., Encarnacao, J. A., Becker, N. I., \& Trenczek, T. E. (2015). Histological and histochemical analysis of the gastrointestinal tract of the common pipistrelle bat (Pipistrellus pipistrellus ).European Journal of Histochemistry , 59 , 2477. https://dx.doi.org/10.4081\%2Fejh.2015.2477

Stumpf, R. M., Gomez, A., Amato, K. R., Yeoman, C. J., Polk, J. D., Wilson, B. A., .. Leigh, S. R. (2016). Microbiomes, metagenomics, and primate conservation: New strategies, tools, and applications.Biological Conservation , 199 , 56-66. https://doi.org/10.1016/j.biocon.2016.03.035

Swanson, K. S., Dowd, S. E., Suchodolski, J. S., Middelbos, I. S., Vester, B. M., Barry, K. A., .. Cann, I. K. (2011). Phylogenetic and gene-centric metagenomics of the canine intestinal microbiome reveals similarities with humans and mice. ISME Journal ,5 , 639-649. https://doi.org/10.1038/ismej.2010.162

Tamura, K., Stecher, G., Peterson, D., Filipski, A., \& Kumar, S. (2013). MEGA6: molecular evolutionary genetics analysis version 6.0.Molecular Biology and Evolution , 30 , 2725-2729. https://doi.org/10.1093/molbev/mst197

Tawfik, S. A., Azab, M. M., Ahmed, A. A. A., \& Fayyad, D. M. (2018). Illumina MiSeq sequencing for preliminary analysis of microbiome causing primary endodontic infections in Egypt. International Journal of Microbiology , 2018 , 2837328. https://doi.org/10.1155/2018/2837328

Turnbaugh, P. J., Ley, R. E., Mahowald, M. A., Magrini, V., Mardis, E. R., \& Gordon, J. I. (2006). An obesity-associated gut microbiome with increased capacity for energy harvest. Nature , 444 , 1027-1231. https://doi.org/10.1038/nature05414

Ubeda, C., Bucci, V., Caballero, S., Djukovic, A., Toussaint, N. C., Equinda, M., .. Taur, Y. (2013). Intestinal microbiota containingBarnesiella species cures vancomycin-resistant Enterococcus faecium colonization. Infection and Immunity , 81, 965-973. https://dx.doi.org/10.1128\%2FIAI.01197-12

Vandžurová, A., Piliš, V., Bačkor, P., Júdová, J., Javorský, P., \& Faix, Š. P. P. (2012). Microflora of the bat guano. Folia Veterinaria, $56,68-69$.

Wang, L. F., Walker, P. J., \& Poon, L. L. (2011). Mass extinctions, biodiversity and mitochondrial function: are bats 'special'as reservoirs for emerging viruses?. Current Opinion in Virology , 1 , 649-657. https://doi.org/10.1016/j.coviro.2011.10.013

Wang, J., Linnenbrink, M., Künzel, S., Fernandes, R., Nadeau, M. J., Rosenstiel, P., \& Baines, J. F. (2014). Dietary history contributes to enterotype-like clustering and functional metagenomic content in the intestinal microbiome of wild mice. Proceedings of the National Academy of Sciences of the United States of America , 111 , 2703-2710. https://doi.org/10.1073/pnas.1402342111

Wang, W. L., Xu, S. Y., Ren, Z. G., Tao, L., Jiang, J. W., \& Zheng, S. S. (2015). Application of metagenomics in the human gut microbiome.World Journal of Gastroenterology , 21 , 803-814. https://dx.doi.org/10.3748\%2Fwjg.v21.i3.803 
Whitaker, J. O. Jr., Dannelly, H. K., \& Prentice, D. A. (2004). Chitinase in insectivorous bats. Journal of Mammalogy , 85 , 15-18. https://doi.org/10.1644/1545-1542(2004)085\%3C0015:CIIB\%3E2.0.CO;2

Whitaker, J. O. Jr., Ritzi, C. M., \& Dick, C. W. (2009). Collecting and preserving ectoparasites for ecological study. In Kunz, T. H. \& Parsons, S. (Eds.), Ecological and Behavioral Methods for the Study of Bats . (2nd ed). (pp. 806-827). Baltimore: The John Hopkins University Press.

Wibbelt, G., Speck, S., \& Field, H. (2009). Methods for assessing diseases in bats. In Kunz, T. H. \& Parsons, S. (Eds.), Ecological and Behavioral Methods for the Study of Bats . (pp. 775-794). Baltimore: The John Hopkins University Press.

Wilson, D. E., \& Mittermeier, R. A. (2019). Handbook of the Mammals of the World . Barcelona: Lynx Edicions.

Wilson, D. E., \& Reeder, D. M. (2005). Mammal Species of the World: A Taxonomic and Geographic Reference . Baltimore: The John Hopkins University Press.

Zhang, T., Wu, Q., \& Zhang, Z. (2020). Probable pangolin origin of SARS-CoV-2 associated with the COVID-19 outbreak. Current Biology , 30 , 1346-1351. https://doi.org/10.1016/j.cub.2020.03.022

\section{Legends}

Table 1. List of samples and their sources used for microbiome analysis.

Table 2. Number of effective 16S rRNA gene sequences, number of observed OTUs, alpha diversity indices (Chao1, Shannon, and Simpson), and evenness of the bacterial community in four island populations. ${ }^{*}$ The operational taxonomic units (OTUs) were defined at the $97 \%$ similarity level.

Table 3. Relative abundance of microbiome communities at the phylum level in different populations.

Table 4. Relative abundance of microbiome communities at the family level in different populations.

Table 5. The correlation coefficient values (Pearson r) and p-values (bold ) between bacterial communities (genera) from island populations.

Figure 1. Map of sampling locations of P. hypomelanus in Peninsular Malaysia.

Figure 2. Dissection of island flying fox.

Figure 3. E-gram of PCR products from B3 sample (Pangkor Island).

Figure 4. The rarefaction curve for OTUs defined at $97 \%$ similarity for different populations of P. hypomelanus. Vertical axis shows the number of OTUs, and horizontal axis shows the number of samples sequenced.

Figure 5. Phylum level distribution in the bacterial communities among populations. Vertical axis shows locality, and horizontal axis shows the percentage of relative abundance.

Figure 6. Family level distribution in the bacterial community among populations. Vertical axis shows locality, and horizontal axis shows the percentage of relative abundance.

Figure 7. Heatmap with dendrogram at the genus level using a gradient heatmap (over $1 \%$ of the microbiome). The 30 most predominant genera were used in hierarchical clustering to evaluate the relationships between four populations of $P$. hypomelanus using weighted pair clustering based on Bray-Curtis measurements. The lighter color indicates higher abundance.

Figure 8. The Venn diagram illustrates the number of shared OTUs at the $97 \%$ similarity between four populations. Intersection between circles indicates the number of shared OTUs.

Figure 9. Phylogeny comparison of four populations inferred from relationships between microflora communities and the host phylogeny reported previously (Mohd-Yusof et al., 2019). The two phylogenies were found to be statistically different. Values adjacent to nodes are bootstrap values. 
Figure 10. A three-dimensional plot of weighted UniFrac-based principal coordinate analysis (PCoA). Plot was created using the pairwise weighted UniFrac distances which represent richness and evenness of microbial species. PC1 is variability at $40 \%, \mathrm{PC} 2$ is variability at $20 \%$, and PC3 is variability at $17 \%$. Different shapes indicate different locality.

Figure 11. The cold-hot plot shows the correlation between the bacterial communities (genera) from four island populations.

\section{Hosted file}

Table 29 May.docx available at https://authorea.com/users/329202/articles/456248-firstreport-on-metagenomic-analysis-of-gut-microbiome-in-island-flying-fox-pteropushypomelanus-revealing-latitudinal-correlation-as-opposed-to-host-phylogeny-in-islandpopulations-of-malaysia

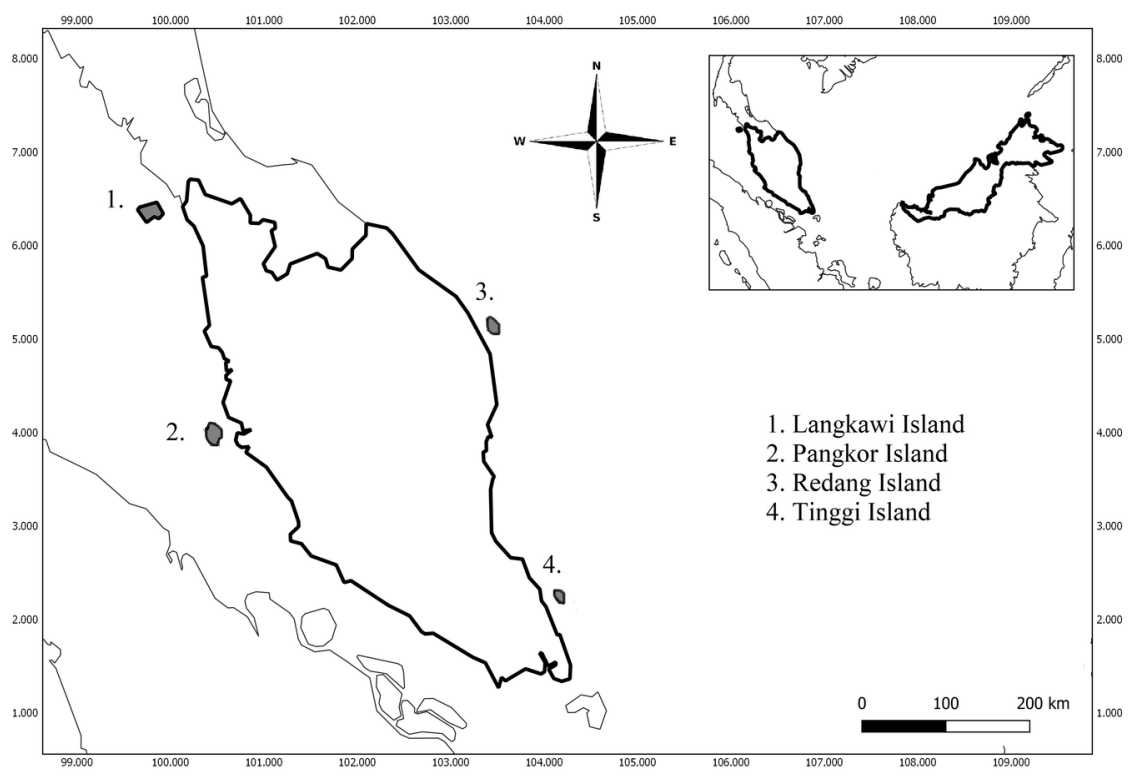



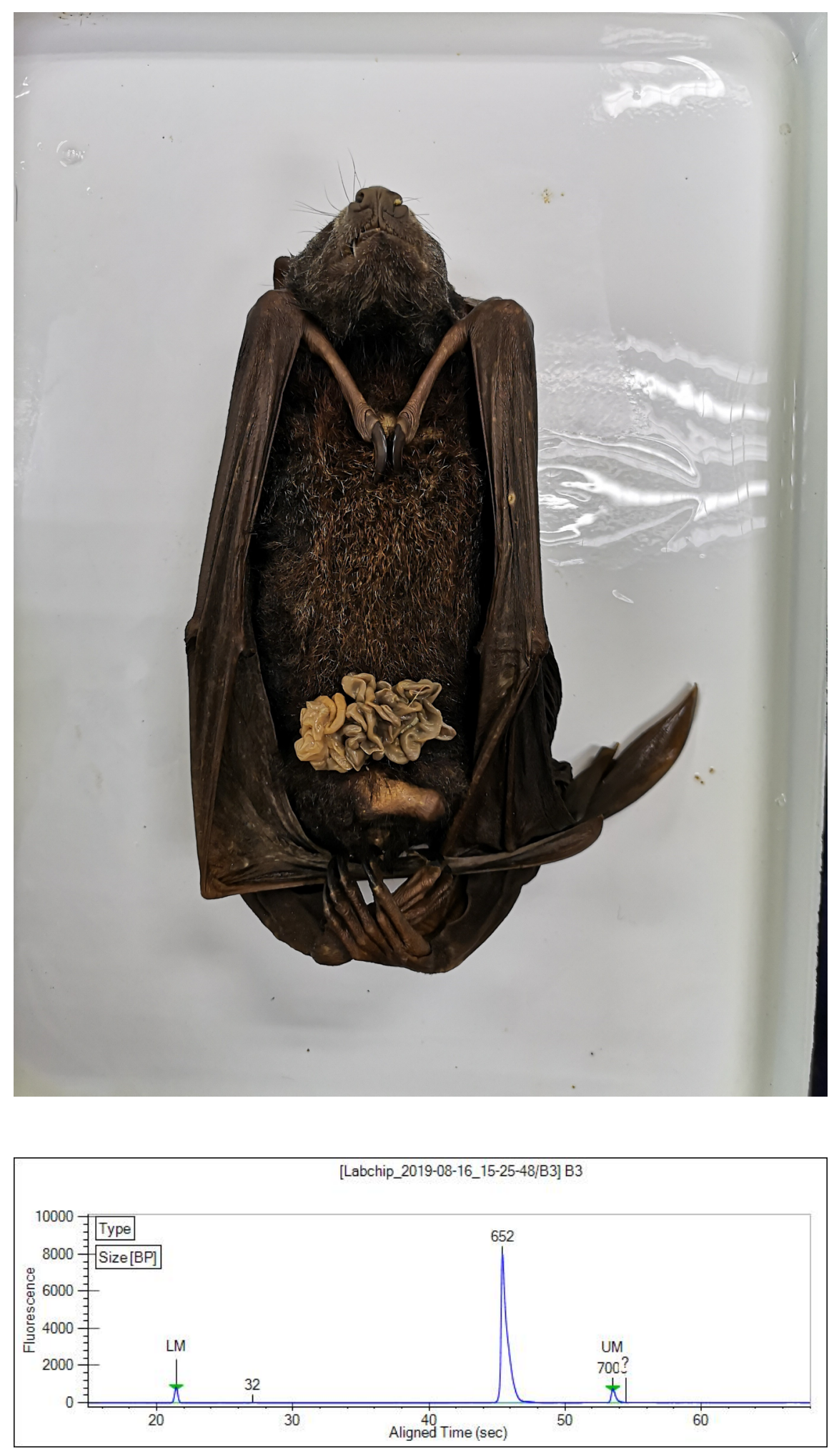

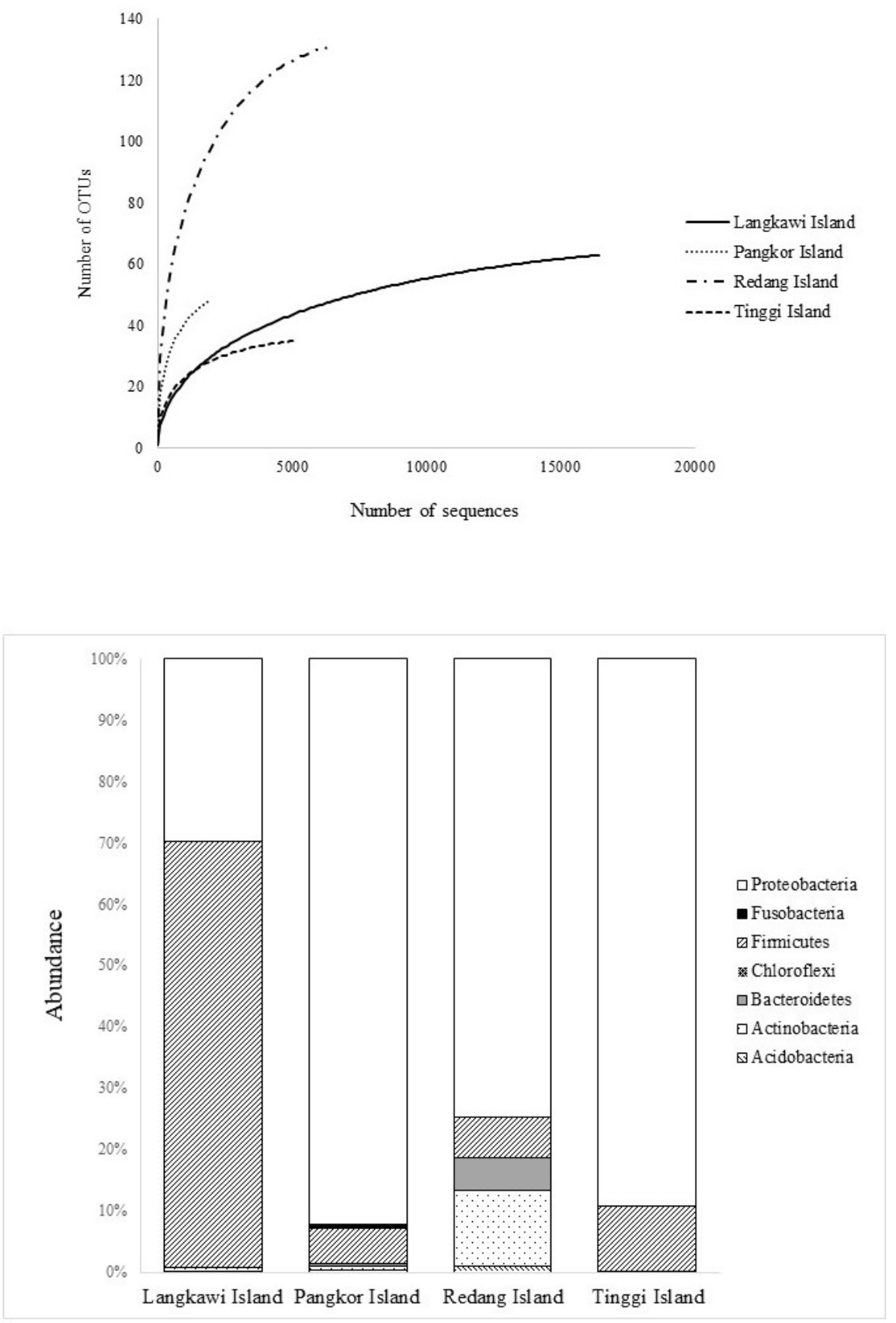


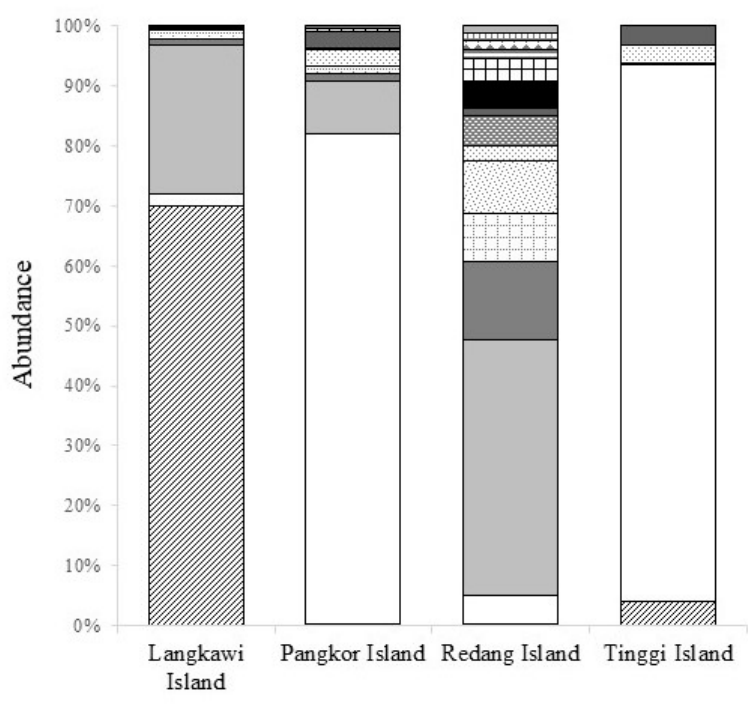

$\square$ Alteromonadaceae

$\square$ \{Unknown Family\} Solibacterales

$\square$ Pseudoalteromonadaceae

日Idiomarinaceae

$\square$ Propionibacteriaceae

- Halomonadaceae

口Gemellaceae

口Flavobacteriaceae

$\square$ Clostridiaceae

$\square$ Micrococcaceae

$\boxminus$ Bradyrhizobiaceae

$\square$ Rhodobacteraceae

$\square$ Pseudomonadaceae

$\square$ Enterobacteriaceae

Q Streptococcaceae

angkawi 


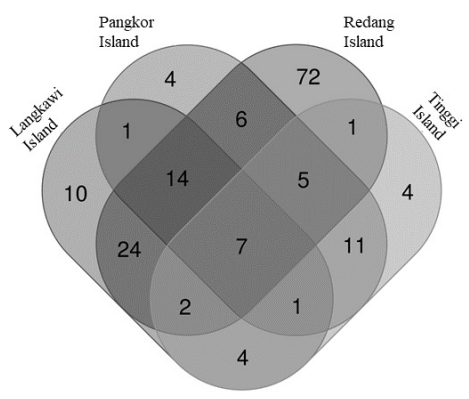

Metagenomic relationships

Host phylogeny
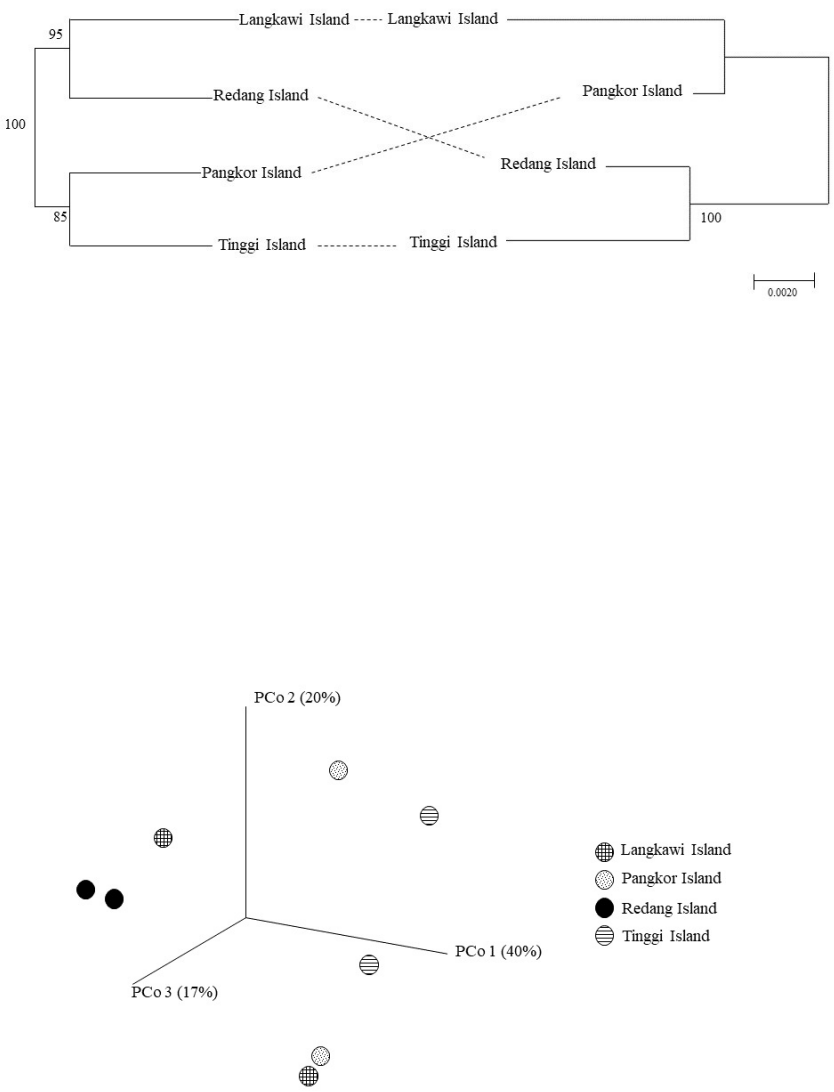


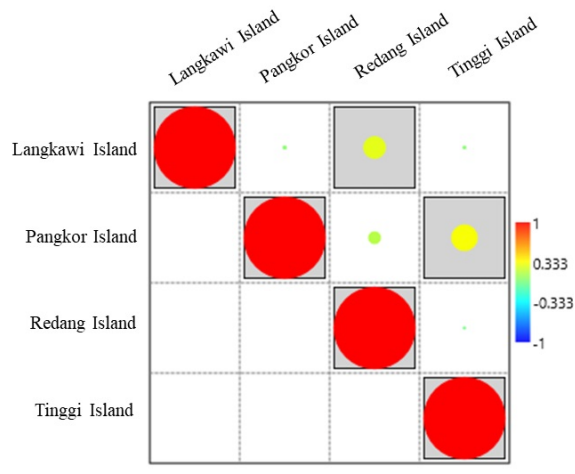

